This is an Accepted Manuscript of an article published by Taylor \& Francis in The Journal of Modern Craft on 28/04/17, available online:

https://www.tandfonline.com/doi/full/10.1080/17496772.2017.1294365. 


\section{The Crusoe Condition: Making within Limits and the Critical Possibilities of Fiction}

Dr Catharine Rossi is a Senior Lecturer in Design History at Kingston University. Her publications include Crafting Design in Italy: from postwar to postmodernism (Manchester: Manchester University Press, 2015).

\section{ADD ABSTRACT and KEYWORDS}

Imagine you are on a desert island off the South American coast, or perhaps a traffic island below a London motorway. You are alone, the sole survivor of a shipwreck, a car crash, an environmental or other disaster that has removed you from civilization, and it from you. At first you despair, but then you learn to make what you need to live using your habitat's resources. You survive.

This story is no doubt familiar. It first appeared in 1719 as Daniel Defoe's The Life and Strange Surprizing Adventures of Robinson Crusoe, Of York, Mariner: Who Lived Eight and Twenty Years, All Alone in an Un-Inhabited Island on the Coast of America, Near the Mouth of the Great River of Oroonoque; Having been Cast on Shore by Shipwreck, Wherein all the Men Perished but Himself. With An Account How He Was at Last as Strangely Deliver'd by Pyrates. This elaborately titled fictionalization of a real-life castaway tells the story of Robinson Crusoe, an English merchant and lone survivor of a shipwreck during a slave-buying mission to West Africa in 1659. ${ }^{i}$

Even if you have not read the novel you have doubtless encountered a "Robinsonade," a nineteenth century neologismused to describe the countless imitations, adaptions, and revisions that have appeared since then. ${ }^{i i}$ The story has been transposed into multiple genres and geographies, including Johan David Wyss's children's tale The Swiss Family Robinson (1812), JG Ballard's dystopian Concrete Island (1974), the story of a plane-crash surviving postman in Cast Away (2000), and

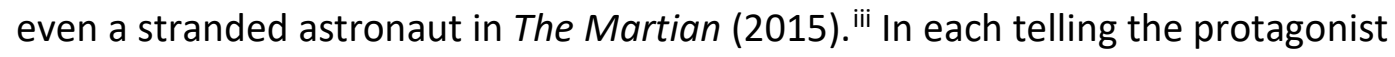
improvises with their material surroundings to make their survival.

Robinson Crusoe has a mythic status in Western culture. ${ }^{\text {iv }}$ It is a persistent presence whose specifics of place, genre and message have altered in line with broader societal shifts, from the early modern imperialism of Defoe's era to today's globalized condition. Widely accepted as the first English novel, Robinson Crusoe has been mobilized by thinkers from Karl Marx to Jean-Jacques Rousseau and Virginia Woolf, and has been subject to extensive academic interpretation, in literary and postcolonial studies, as well as economics and theology. ${ }^{\vee}$ Yet the novel has been surprisingly overlooked in craft and design history. This is a lamentable absence, for as this article explores, Robinson Crusoe has a lot to give both disciplines: notwithstanding their respective emphasis on artisanal and industrial production, each includes a focus on the making, an act that is at the narrative's core. 
Woolf praised Defoe's focus on making as part of his elevation of everyday undertakings: "he comes to make common actions dignified and common objects beautiful. To dig, to bake, to plant, to build - how serious these simple occupations are; hatchets, scissors, logs, axes - how beautiful these simple objects become." For Woolf the novel's entire meaning lay in these manually made objects, in "the perspective that a plain earthenware pot exacts." "vi As thinkers such as Marx and Rousseau have recognized, the meaningfulness of this "perspective" is as much about the pot's coming-into-being as the object itself, a dual emphasis on making and made things that I will also pursue here.

Everyday making is central to the survivalist novel because making is central to our survival. In the novel, it occurs in the extraordinary situation following Crusoe's shipwreck. Stranded alone on an island, Crusoe is forced to make by hand everything he needs to live, from shelter, furniture and clothing to artifacts and technologies for food production and storage. As Tanya Harrod, the only craft writer to have examined Crusoe in craft terms, explains: "Defoe's masterpiece charms us because we are set to wondering how we would manage if everything familiar were stripped away, if craft became a dire necessity". vii

The centrality of making can be easily forgotten in post-industrial, wealthy economies such as the UK and USA, where 24/7 consumerism means that survival is predicated not on the ability to make, but to buy; to consume products made by others whose labor is largely concealed and remote. viii Robinson Crusoe strips away the artifice of convenience in consumer societies and forces us to confront the making that underpins our world.

\section{Examining the Meaning of Making in Robinson Crusoe}

Examining the making in Robinson Crusoe is an experiment, one informed by the paucity in both craft and design history of tools to critique contemporary practice. ${ }^{\text {ix }}$ While there has been some use of literature in craft and design history, including in this journal, fiction is one such largely overlooked but potentially valuable tool. ${ }^{x}$ This is evident from Harrod's unusual examination of craft's pre-eminence in science fiction, a genre that includes many Robinsonades. She identifies a trend for returning to a simple, craft-based existence in plots of "that sci-fi sub-genre, the catastrophe novel". Harrod cites twentieth century novels such as Cicely Hamilton's 1922

Theodore Savage, in which a civil servant survives a war-torn Britain by becoming "a toiler with his hands", and Philip K. Dick's 1953 The Variable Man, which sees a time travelling odd job man save a technologically advanced future thanks to his archaic ability to fix. The craft historian shows how twentieth-century science fiction mobilized craft to express concerns about deskilling amidst industrial advance. ${ }^{x i} A s$ this article will explore, Robinson Crusoe can be used to explore similar concerns today.

This article is divided into two halves. The first half focuses on Defoe's original story to explore what kind of maker Robinson Crusoe was, and what his making says about 
craft more generally. The second uses the multiple ideas around making in Robinson Crusoe to examine works by a number of designers from the late twentieth and early twenty-first centuries.

Calling Crusoe a "maker" is intentional. On the one hand, it subscribes to the universalist approach championed by Richard Sennett in The Craftsman; this emphasis on craft as an elementary activity also lies at the center of Tim Ingold's anthropological research. ${ }^{\text {xii }}$ Both Ingold and Sennett's conceptualizations of making come into play here, particularly around questions of skill and empathy with the material world.

On the other hand, using the terminology of "making" reflects my desire to marshal Defoe's novel to interpret contemporary practice. Historically associated with specialized craft identities such as cabinetmakers and shoemakers, today "maker" is a popular, but little-examined, term to describe creative figures who encompass a range of practices.

The maker's composite and complex identity was most visible in the popular 2011 Crafts Council/ V\&A Museum exhibition Power of Making. Featuring everything from a gorilla sculpture made from metal coat hangers to an Arduino programmed quilt, the exhibition exemplified how the term "making" is used to refer to a range of skills, materials and techniques amongst a spectrum of practitioners. . $^{\text {iii }}$ In one sense, this is arguably just an exercise in rebranding, which bespeaks the persistently problematic nature of the word craft itself. On the other hand, there is an equally constructed depiction of the maker as a new identity; the tinkerer adept in digital technologies promoted by the Californian MAKE magazine since 2005, and today found in maker faires and makerspaces all over the world. . $^{\text {iv }}$

While diverse, in both the craft and Silicon Valley representations the maker is someone who has elected to resist the dictates of a hands-off world, even though they may lack the craft practitioner's deep-rooted expertise in one particular skill or material. ${ }^{x v}$ This idea of the maker as an individual engaging in general productivity perhaps for the first time - informs the understanding of Crusoe here.

In the second half of the article, I discuss works by the Italian architect Enzo Mari, the Dutch designer Tejo Remy, and the contemporary British designers Committee and Thomas Thwaites. Some of these figures exemplify the term "designer maker", which has been used to describe the emergence in 1980s Britain of another contemporary manifestation: designers who design and make their own products. Described in a 2001 Crafts Council exhibition as an "industry of one", a term that Harrod also uses to describe Crusoe, the designer maker arose out of a lack of mass manufacturing opportunities as well as a rejection of the industrial ethos. ${ }^{x v i}$

The practice of Mari, Remy and these other designers has either been inspired by, interpreted as, or could be seen to be, a Robinsonade. The template appears in their work in several ways, including a turn to fiction, references to issues of survival, restriction on skills, tools and technology, and a bricolage approach. It is this idea of 
necessity-driven and narrative-led making within multiple limits that I define as the Crusoe Condition.

\section{Crusoe as a Maker: Considering Alienation and Autonomy in Craft}

Crusoe's first characteristic has already been identified; he was a maker driven by necessity. He had to make in order to ensure his survival on what he called "The Island of Despair". xvii Aside from the clothes on his back, the castaway has "nothing about me but a knife, a tobacco-piper, and a little tobacco in a box." He has no shelter, no food, and no weapons to hunt or protect him from the island's wildlife. xviii

Conveniently, what he does have is a shipwreck full of provisions marooned less than a mile from the shore. Crusoe swims out to the wreckage on his first day on the island. There he fashions a wooden raft out of the ship's rigging, an improvised act that characterizes much of his making on the island, and loads it up with the ship's provisions. Despite his impoverishment, Crusoe is careful in his selection:

Rummaging for clothes, of which I found enough, but took no more than I wanted for present use, for I had other things which my eye was more open, as first tools to work with on shore ... the carpenter's chest, which was indeed a very useful prize to me, and much more valuable than a ship loading of gold would have been at the time. ${ }^{\text {xix }}$

Crusoe makes twelve trips to the vessel in all. Each time he selects his supplies pragmatically, choosing tools over gold for example - except on his final trip when he takes some of the ship's stash of coins and precious metals, a decision he later regrets. This prioritization is significant. Removed from the capitalist economy of late seventeenth century England, gold has no value on his island. Only primitive use value, rather than capitalist exchange value, exists. What Crusoe deems useful are tools, as these enable him to produce objects for his own use and so to survive.

Crusoe's closed circle of necessity - in which self-production and consumption are held in direct relation - is praised by Marx in Das Kapital. "Everything produced by him was exclusively the result of his own personal labor, and therefore simply an object of use for himself." ${ }^{x x}$ Crusoe is not just a survivalist maker, but also an unalienated one. This free and harmonious condition is manifested in his record keeping. As Marx describes:

His stock-book contains a list of the objects of utility that belong to him, of the operations necessary for their production; and lastly, of the labour time that definite quantities of those objects have, on an average, cost him. All the relations between Robinson and the objects that form this wealth of his own creation, are here so simple and clear as to be intelligible without exertion. ${ }^{\mathrm{x} i}$

In the 1960s lan Watt continued this Marxian line of interpretation, noting the novel's recreation of "a primitive crafts economy" defined by "varied and inspiring" labor. ${ }^{\text {xii }}$ Watt also identified the reason behind Defoe's decision to take "back the 
economic clock": the novelist knew it would appeal to his readers in eighteenthcentury England, who were experiencing the debilitating effects of the division of labor and concomitant distance from making. Watt cites the example of Crusoe's mastery of baking, no longer a daily domestic act in Defoe's era, because bread had become a locally purchased product. Defoe recognized the disparity between this activity's presence in the novel and its absence in his world: "Tis a little wonderful and what I believe few people have thought much upon, viz., the strange multitude of little things necessary in the providing, procuring, curing, dressing, making, and finishing this one article of bread." $x$ xiii

Any positive reading of craft in the novel however is tempered by less savory aspects of the narrative. In the 1970s economist Stephen Hymer condemned Crusoe as exemplifying colonialist exploitation in his plundering of the island's resources and especially his subjugation of Friday, whom Crusoe saves from being eaten by cannibals but then turns into his servant. ${ }^{x x i v}$ In the 1980s Jean Baudrillard criticized Marx's reading of Crusoe as a pre-capitalist craft economy, arguing that use value is not a natural quality of objects, but that "needs, nature, utility" are as much capitalist constructs as exchange value. Baudrillard sees Marx's appropriation of Crusoe as unwittingly asserting bourgeois idealisms such as "individual autonomy". xxv

The novel's presentation of labor as an autonomous activity is indeed one of its most dangerous myths. Crusoe did manually make all of his own objects - with Friday's help following his own arrival on the island - but he was still dependent on a priori labor performed outside of the island. As Watt points out, through the tools salvaged from the shipwreck "Crusoe is in fact the lucky heir to the labors of countless other individuals", an aspect not addressed by Marx, and which undermines his utopian take on Crusoe's labor. ${ }^{x x v i}$ As Lydia H. Liu has shown in her exploration of ceramic production in Defoe's novel, the idea of Crusoe as "a self-made British hero" was part of Europe's imperialist myth of self-sufficiency, belying the continent's dependence on the creative, scientific and technological advances of elsewhere. ${ }^{\text {xxvii }}$ Exposing this contingency is even more important in today's globalized distributions of design, production and consumption, which conceal the often-exploited labour involved in our material possessions.

Looking at Crusoe's tools reminds us there is no such thing as an "industry of one". Instead, what Harrod describes as such "singlehanded-ness - central to the story of modern craft" is itself a fiction. ${ }^{\text {xxviii }}$ However geographically distant he may be from the production involved in his tools, and however much he may appear to be in control of his own labour, Crusoe's making, like that of all makers, is implicated in a globally distributed economic structure. Questions around the ethical nature of the making in the novel, just as in real life, need to consider how tools are produced, as well as how they are used by makers.

\section{The Amateur Crusoe}


Consistent with Crusoe's identity as a maker defined by necessity is his status as an amateur - though not in the usual sense of a leisure-time enthusiast. Crusoe does not choose to be an amateur, but becomes one by default; prior to his arrival on the island he was a merchant. Deciding he needs to make a chair and table, he confesses that:

I had never handled a tool in my life, and yet by labour, application and contrivance, I found at last that I wanted nothing but I could have made it, especially if I had had tools; however I made an abundance of things, even without tools, and some with no more tools than an adze and a hatchet, which perhaps were never made that way before, and that with infinite labour. ${ }^{\text {xix }}$

Crusoe succeeds in making a chair and table, as well as a host of other objects, including clothes, wicker and clay vessels, tool storage, and even a folding umbrella. While he could be seen to embody the freedom and autonomy that craft theorist Stephen Knott ascribes to amateurs in capitalist economies, qualities that Marx clearly saw in Crusoe, his labor was not actually entirely self-determined. ${ }^{\mathrm{xxx}}$ Crusoe was hampered by limitations of skill and tools, restrictions that Knott describes as fairly typical of amateurs, who are "beset by limitations, whether to do with inadequate materials or tools, or a lack of space and time." ${ }^{\prime x x i}$

Crusoe's amateur status also causes him to be slow and error prone. In one desperate instance, he decides to make a canoe to escape his island. It is a lot harder than he had anticipated. It takes five months of "infinite labour" to make the boat; first he must hack down the tree, then work it into a suitable shape, mostly using a "mere mallet and chisel". Unfortunately he is undone by his lack of expertise: on completing the canoe, he finds it too heavy to lift into the water. ${ }^{x x x i i}$ In this instance, amateur making is wasteful labor.

Crusoe is also limited by the fact that he does not know how things are made. ${ }^{\text {xxxii }}$ On deciding to make a wheelbarrow he realizes that "I had no notion of, neither did I know how to go about" how to make a wheel, and so has to give up on the idea. The same happens when it comes to making earthenware pots to store food, "which indeed I wanted sorely, but knew not where to come at them." xxxiv He repeatedly fails, and although his efforts eventually pay off, both the process and results are undermined by his limited skill set:

After having laboured hard to find the clay, to dig it, to temper it, to bring it home and work it, I could not make above two large earthen ugly things, I cannot call them jars, in about two months labour. ${ }^{\mathrm{xxx}}$

Crusoe has better success when he decides to make some baskets, thanks to what he calls an "excellent advantage" from his childhood in England:

When I was a boy, I used to take great delight on standing at a basket-makers in the town where my father liv'd, to see them make their wicker-ware; and 
being, as boys usually are, very officious to help, and a great observer of the manner how they work'd those things, and sometimes lending a hand, I had by this means full knowledge of the methods of it, that I wanted nothing but the materials. ${ }^{\mathrm{xx} x \mathrm{i}}$

Crusoe finds some willow-like branches, and employs himself in "making, as well as I could, a great many baskets." xxxvii Crusoe learned by watching the performance of process, and then he replicates what he had observed. As such he affirms the value of what Sophie-Ann Lehmann calls "showing making", a genre characterized by depictions that date back to Ancient Egypt, and which has been key to the transmission of craft knowledge since then. ${ }^{x \times x v i i i}$

The baskets Crusoe makes are those of an unskilled amateur: "tho' I did not finish them very handsomely, yet I made them sufficiently serviceable for my purpose." "xxix Like the "ugly" ceramic vessels, Crusoe cannot make "handsome" baskets. His lack of skill in manipulating clay and wood means that Crusoe is even more subject to their material agency - a dynamic that Ingold discusses, coincidentally using the example of his own attempts in willow basketry. ${ }^{\mathrm{xl}}$

From a Marxian perspective, the vessels' aesthetic appearance does not matter; they still function as vessels and so still have the all-important use value. Their roughness also asserts the authenticity of this unalienated amateur's manual making. They subscribe to the idea of the "true finish" or "lovely form" that William Morris and John Ruskin respectively called for a century later, which equated irregularities and imperfection with creative freedom, as opposed to the inhuman perfection of machine production. ${ }^{x i}$ While Morris and Ruskin romanticized this aesthetic as illustrating free craftsmanship, it is Crusoe's amateur status that engenders such authentic looking craft.

Crusoe does improve his making abilities. With his earthenware he graduates from making sun-dried vessels to fired and glazed pots, and "in my wicker ware I also improved much, and made abundance of necessary baskets." "xlii He exemplifies Sennett's prescription for becoming skilled: amateurs, like all makers, start off unskilled, and only improve through practice over a long duration. ${ }^{\text {xliii }}$

\section{Making on an Island: Improvisation}

Lack of skills and tools belong to a larger set of limitations that Crusoe faces. He is on an island, a geographical typology defined by boundedness and separateness, as Rod Edmond and Vanessa Smith have described in their history of islands and their representation. ${ }^{\text {liv }}$ His location means his resources are necessarily limited, despite the verdant terrain and what Watt describes as the "deus ex macchina" of his wellstocked shipwreck. ${ }^{\text {xlv }}$

Crusoe's making-within-limits is an example of bricolage, a word that Claude LéviStrauss's used to describe DIY activities, which he postulated as a representation of 
an "untamed state" in his book The Savage Mind: "his universe of instruments is closed and the rules of his game are always to make do with 'whatever is at hand'... with a set of tools and materials which is always finite." "xlvi As the anthropologist Trevor Marchand similarly argues, finitude "promotes improvisational strategies" in the maker, traits evident in Crusoe's making. xlvii

Crusoe repeatedly has to make do and improvise with what is available; from his fashioning of a raft on the shipwreck to his failed attempts to transform a tree trunk into a canoe, his more successful use of willow-like materials to make baskets, and his decision to fashion a hodd as an alternative to the unrealisable wheelbarrow. Most impressively, he even manages to construct a kiln, even though he had "no notion" of how to make one, by heating up his earthenware vessels over an open fire, and tending to them overnight. ${ }^{\text {.lviii }}$

Bricolage has considerable currency today. It chimes with critiques of a model of progress that is based on endless growth and infinite resources -- an industrial vision challenged by twenty-first century evidence of mankind's detrimental impact on the planet. As Steven Jackson argues in relation to technological innovation, there has to be "an appreciation of the real limits and fragility of the worlds we inhabit-natural, social, and technological - and a recognition that many of the stories and orders of modernity ... are in process of coming apart." xlix Jackson argues for a different idea of innovation, one based on the innovative possibilities of limits, which Crusoe's island embodies.

This idea of innovation born out of limitation is evident in multiple creative theories today. It can be seen in the championing of jugaad, a Hindi term that describes frugal innovation based on the resources available, and the Fab City movement's advocation of self-sufficient cities, a mantra spreading among makers from Amsterdam to Shenzhen. ' It is visible in what the architecture curator Lydia Kallipoliti has called the persistence of "closed systems" in twentieth and twenty-first century architecture, design and engineering, evident in everything from self-built rural communities to designs for space capsules and submarines. ${ }^{\text {li }}$ The message from all of these voices is that constraints engender creativity.

Yet as has already been suggested above, the novel's depiction of a finite and closed production is its most contentious aspect. The idea that Crusoe is making autonomously is the novel's biggest fiction, and most dangerous message about making. At its worst, such an island mentality promotes the idea of separatist individualism, regardless of whatever chaos is going on in society outside. ${ }^{\text {lii }}$ Nevertheless, as the next section will explore, bricolage is an attractive idea to contemporary designers, and it does have genuine promise. No man may be an island, but our planet is one: we need to become like the bricoleur Crusoe, surviving and innovating in ways that respect the limits of our world. 
This first part of this article focused on establishing some key traits of Crusoe as a maker. He is driven by necessity, an unalienated amateur who improvises with the limited tools and materials available on his island. This second, shorter part considers how these characteristics map onto a number of designers who can be seen to have engaged with Crusoe-like making. Curiously, the qualities of this pre-industrial, seventeenth century designer resonate strongly with post-industrial design of the late twentieth century. If Defoe imagined a primitive craft-based economy for Crusoe in order to appeal to his industrial age readers, it is worthwhile considering why these designers are recreating these back-to-basic conditions over two hundred years later.

My first example of a Robinsonade design, which in fact inspired this article, comes from 1970s Italy, a context in which a handful of Marxist-inspired architects positioned craft as a utopian vehicle to liberate a creativity they believed suppressed

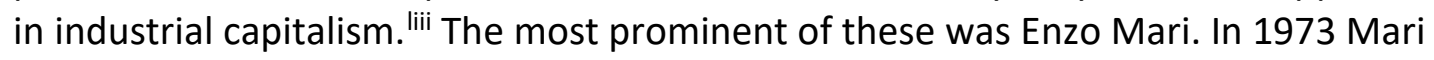
launched Autoprogettazione (self-design), a project in which users could selfproduce furniture, including tables, chairs and a bed, using designs that Mari distributed for free through a manual. The designs could be realized with just a hammer, nails and pre-processed timber planks, and were intended to be simple enough for anyone to make: the project relied on the limited skills and tools of the amateur, just like Crusoe on his island. liv Autoprogettazione was strongly motivated by the architect's Marxist politics: through engaging in self-production, he believed that domestic, amateur producers would awaken to the commodity fetishism in the design market. ${ }^{\text {Iv }}$

While Crusoe is tacitly suggested by Mari's reliance on limited skills and equipment, it is in the dimension of critique that he made an explicit appearance. Writing in 1974, the art critic Giulio Carlo Argan channeled Marx's reading of Crusoe, describing Mari as imagining alienated consumers inhabiting "the mega-necropolises of neocapitalism like Robinson on his island. To survive you have to start making the tools with which to construct an environment to live in ... everyone has to design; after all, it's the best way to avoid being designed. ${ }^{\text {Ivi }}$

Argan emphasized the importance of making to survival, albeit in the alienating conditions of neocapitalism rather than the life-threatening situation of a shipwreck. Like Marx, he attributes Crusoe's unalienated condition to his tool-based selfproduction. But he also saw that tools, as much as the resulting products, need to be factored in to considerations of agency and autonomy in making.

In Italy's Marx-inflected design avant-garde it was Crusoe's unalienated condition that provided the greatest inspiration. A different Crusoe trait grew in popularity amongst architects and designers more generally in the 1970s and 1980s: adhocism. A synonym of bricolage, the term adhocism was coined by Charles Jencks and Nathan Silver. The American architects knew that this was not a new way of making. It could be traced back to Defoe's era: "adhocism has always been around. (Think Robinson Crusoe, making a raft and then a shelter from the wreck of his ship)." "lvii It had however gained purchase in the conditions of incipient postmodernism; 
adhocism defied modernism's emphasis on the new and its idealization of endless progress in favor of a creativity predicated on sorting through the shipwreck of culture, creating artifacts that revealed their relationship to the past. Iviii

Jencks identified multiple types, or "stages" of adhocism. The first describes Crusoe's making, when adhocism is the only option available: this is the "ad hoc breakthrough", the moment of creation when "two or more elements are brought together in a new synthesis". The second is what defines the majority of adhoc creations, a "simulated adhocism" in which hybridity and differentiation are celebrated. In this creative approach, the maker purposefully imitates the features of first-order bricolage, the Crusoe condition. ${ }^{\text {lix }}$

"Simulated adhocism" can be seen in Andrea and Nicoletta Branzi's Animali Domestici 1985 furniture series. ${ }^{\mid x}$ This self-described "neo-primitivist" collection consisted of an aesthetically and materially fragmented combination of raw woods and industrially processed materials. ${ }^{\mid x i}$ Andrea Branzi described the furniture as if it had been created by "those who, having fallen from an airplane into the middle of the Amazon territory, find themselves operating with technologically advanced elements still on board, as well as with the natural materials of the forest.'" Branzi used this story to illustrate his championing of a postmodern design culture in which "progress [is] no longer valued; instead the unexpected is valued". lxii His use of this Robinsonade is telling; it not only shows the importance of narrative in postmodern design, but also suggests that survival is dependent on a bricolage approach that brings together technology and nature, rather than the dominance of the former over the latter.

The use of storytelling in Animali Domestici resonates with Crusoe's appearance in the narrative-led adhocism of 90s Dutch design. Ixiii Tejo Remy's You Can't Lay Down Your Memories, designed in 1991 and included in Droog's inaugural collection in 1993, is a seemingly haphazard arrangement of readymade drawers and bespoke maple casings, banded together with a fabric strap that users are invited to rearrange into different configurations. Ixiv According to the curator Ida Van Zijl, the furniture was a metaphor for Crusoe's island, with Remy, and also arguably the user, pretending to be the already fictional bricoleur. ${ }^{\mathrm{xv}}$

You Can't Lay Down Your Memories combines aspects of both Autoprogettazione and Animali Domestici. On the one hand it offers a depoliticized take on the importance of agency and control in making material surroundings our own; on the other, it promotes the diversity that Branzi championed. Crusoe offers a way to correlate these designs to one another, and also exposes a shared concern with incorporating users in design projects, as well as questions of agency, and creativity within limitations in late twentieth century design.

\section{Crusoe Making Today}

Mari, Branzi and Remy anticipated the widespread interest in making amongst young designers today. As with the engagement with making more generally, this covers a 
variety of approaches and activities, from craft-orientated designer makers to more speculative designers. ${ }^{\text {Ixvi }}$ They include a small but notable group who are exploring their interest in manual making through Crusoe-like scenarios of self-imposed limitations.

This is evident in Thomas Thwaite's The Toaster Project from 2009. This was inspired by another Robinsonade episode, from Douglas Adams' Hitchhikers Guide to the Galaxy series, in which Arthur Dent survives earth's destruction only for his spaceship to crash onto the planet of Lamuella, an interstellar version of Crusoe's shipwreck. Adams describes how the twentieth century everyman believes he can conquer its technologically inferior inhabitants, but realizes that while he comes from a world of what he calls "computers and ballet and Armagnac he didn't, by himself, know how any of it worked. Left to his own devices he couldn't build a toaster. He could just about make a sandwich and that was it". Ixvii Like Crusoe, Dent has to face up to the fact that he does not know how to make the manifold technologies on which his existence is contingent.

Thwaites uses this story to illustrate his real-world concern at his lack of knowledge at how toasters, as well all the other domestic appliances that fill our homes, are made. He decided to find out by making a toaster himself, from scratch. Feeding in issues around the demise of manufacturing in his native Britain, he travels around his own island, attempting to solitarily replicate the toaster's globally distributed industrial manufacture. Like Crusoe, Thwaites had no idea of how his everyday was made when he began, and so was similarly in the position of an unskilled amateur when it came to recreating the technologies involved. Also like Crusoe, he had to improvise, often using more primitive methods than would conventionally be used: in order to smelt iron ore he consulted a sixteenth century treatise on metallurgy, for example, although he ended up abandoning this in favor of using a microwave. Clearly playing Crusoe only needs to go so far when you're only pretending. ${ }^{\text {Ixviii }}$

Like Crusoe's wicker baskets and "ugly" ceramic vessels, Thwaites's toaster is not "handsome". But, like Crusoe's vessels, it fulfills its function; not very well as a toaster, but as a means to tell a story, about the problematic nature of our globalized production system. The project shows what happens when you try to replicate mass manufacturing as an individual maker. Its messy plastic surfaces could be seen to assert the aesthetics of authenticity that Morris advocated. However the toaster's imperfect appearance and non-functionality is also a riposte to the autonomous and craft-based production that such a project could be seen to promote. As Stuart Walker has described, the project reacts against "the romantic notion that arises in some ecology dialogues of retreat, of pursuing a more selfsufficient and insular lifestyle." "xix The idea of return to craft-based existence is exposed as incompatible with our desire for the convenience of modern commodities. The Toaster Project affirms the critique of the myth of autonomy in Crusoe: we need to recognize our interdependence on others, and the responsibility that comes with such globally connecting manufacturing. It also shows the possibilities of fiction in both inspiring, and interpreting, design practice. 
Thwaites is not the only designer deploy the story of a solitary, island-bound maker to question the value systems of contemporary design. Committee, the London based duo of Harry Richardson and Clare Page, instigated their The Last Man project in 2013. Like the Branzis, they set up a Robinsonade as the basis for their project, imagining that "there has been no disaster, the buildings stand, the shelves are still stacked, there are simply no other people." "1xx All that is left is one unskilled office worker, a modern version of the merchant Crusoe, who begins to exercise their desire to improve their existence through redistributing and reimagining their material surroundings: in other words, an amateur engaged in bricolage.

According to the designers, this is not a dystopian scenario, but rather a thought experiment that allows them to consider what would result if there were no economic, cultural, social or other factors shaping, or inhibiting, design. The project seems to echo Sennett in its suggestion that the impulse to make, or remake, our environment is universal. Even if Crusoe didn't need to make in order to survive, he would have felt compelled to do so anyway.

The first iteration of the ongoing project, called "Improvement", took place at Kingston University's Stanley Picker Gallery in 2013. Committee invited visitors to borrow one of fifty found objects, including a towel stand, chair and baluster and become "the last man", improving it however they wished over a twenty-four hour period, before returning it to the Gallery for another participant to improve. The results, which saw the towel stand and chair come together as a sledge, and the baluster reconfigured into a hammer, inevitably reveal their earlier adaptations, producing a bricolage in extremis by the end of the three week period. They are a largely absurd, comical selection of objects, which seem far removed from the necessity-driven making of Crusoe. Yet Committee's imagining of an uninhabited bounded utopia outside of time, space, and capitalist logic, in which making is driven purely by what an individual feels the need to make, suggests that The Last Man is perhaps the strongest example of a Crusoe condition in contemporary design.

\section{Conclusion}

I will end this article by returning us to Robinson Crusoe, the solitary, amateur designer maker driven to make in order to survive his island imprisonment. Crusoe offers a means to understand the practice of a growing group of designers today; those self-producing objects that are indexical of their manual and often (sometimes simulated) improvised making, driven by a desire to produce design that critiques our contemporary condition and suggests alternatives to improve it. That critics such as Argan and Van Zijl have used Crusoe to interpret these designers' work, and the fact that designers are themselves adopting the guise of storytellers to create Crusoe-like artifacts and scenarios that help us understand our present condition, only affirms the value of Defoe's novel, and fiction more generally, in interpreting craft and design. 
Of course Robinson Crusoe is not unproblematic as a source or critical tool. Alongside the partiality of the perspective it offers, and its debatable morals and ideology, is the potentially simplistic reading of a much-studied work. Yet there is no doubting that Crusoe has a critical validity today, as we face up to an ever-nearer future based on island-like limits - be it in concepts of post-growth economy, frugal innovation, or off-shoring manufacturing. Crusoe reminds us of the centrality of making in our world; that we need to make in order to survive, and we need to think about what type of making goes on in our world; from the authentic making of the solitary crafts practitioner to the obscured making of the tools on which making depends. We should therefore take this particular fiction seriously, particularly when we are dealing with the rich stories that handmade objects contain, as it helps us to understand the narrative being constructed through and around craft and design today.

\footnotetext{
'The story was based on the life of Alexander Selkirk, a Scottish sailor who was marooned on an island off the Chilean coast in 1704 for four and a half years. John Richetti, "Introduction," in Daniel Defoe, Robinson Crusoe ed. by Richetti (London: Penguin Books, 2003), p. xiv.

ii Maria Luz Suárez, Robinson Crusoe Revisited: Contemporary Revisions of the Robinson Crusoe Myth (Braunton: Merlin Books Ltd., 1996), p. 1.

iii JG Ballard, Concrete Island (London: Harper Perennial, 2008); Johan David Wyss, The Swiss Family Robinson (Ware: Wordsworth Editions, 1993); Cast Away, dir. Robert Zemeckis (2000); The Martian, dir. Ridley Scott (2015).

iv lan Watt, "Robinson Crusoe as a Myth," Essays in Criticism: A Quarterly Journal of Literary Criticism 1(2) (1952): $96-97$.

$\checkmark$ Pat Rogers, Robinson Crusoe (London: George Allen \& Unwin, 1979), p. 1. For an overview of some of the manifold interpretations of Crusoe, see Frank H. Ellis (ed.), Twentieth Century Interpretations of Robinson Crusoe: A Collection of Critical Essays (Englewood Cliffs, New Jersey: Prentice-Hall, 1969). vi Virginia Woolf, "Robinson Crusoe," (1932), reprinted in Ellis (ed.), Twentieth Century Interpretations of Robinson Crusoe, pp. 19 - 24.

vii Tanya Harrod, “Classic Take on the Industry of One," Crafts January/February (2014): 92.

viii For more on 24/7 society see Jonathan Crary, 24/7: Late Capitalism and the Ends of Sleep (London: Verso, 2014)

ix Paul Greenhalgh; "Review Article: Words in the World of the Lesser: Recent Writings on Crafts," Journal of Design History 22 (4) (2009): 401 - 402. Jessica Hemmings, "Textile Theory: Do we Need It?," in Javier Gimeno-Martinez and Fredie Floré (eds), The Seventh ICDHS Conference Design and Craft: a History of Convergences and Divergences (Weteren: Universa Press), p. 210; Royal College of Art, Design History of Now: Using Design History's Methods and Perspectives to Understand the Present, http://historyofnow.rca.ac.uk/about/ (last accessed 23 June 2016)

× Adamson and Harrod, "Interview with AS Byatt," The Journal of Modern Craft (4)1 (2011): 65 - 82; Idris Parry, "Rilke and Things," The Journal of Modern Craft, 7:3 (2014): 285-295

xi Cicely Hamilton, Theodore Savage (Boston, MA; Brooklyn, NY: HiLo Books, 2013), p. 19; Philip K. Dick, The Variable Man (London: Sphere Books, 1977); Harrod, "How to Survive the Coming Stone Age," Crafts, May/June, 2011, 108; Harrod, The Crafts in Britain in the Twentieth Century (New Haven, Conn.: published for The Bard Graduate Center for Studies in the Decorative Arts by Yale University Press, 1999), p. 155.

xii Richard Sennett, The Craftsman (London: Allen Lane, 2008), p. 6.

xiii The Power of Making was curated by Daniel Charny and held at the V\&A Museum from September 2011 to January 2012. Charny (ed.), The Power of Making: The Importance of Being Skilled (London: V\&A Publishing, 2011)
} 
xiv Catharine Rossi, "The Maker 2.0: A Craft-Based Approach to Understanding a New Creative Identity," in Leah Armstrong and Felice McDowell (eds.), Fashioning Professionals (London; New York: Bloomsbury, forthcoming), n.p.

${ }^{x v}$ Rosy Greenlees, Email interview with the author, 16 ${ }^{\text {th }}$ September 2016.

xvi David Redhead, Industry of One: Designer-Makers in Britain 1981 - 2001 (London: Crafts Council, 2001); Harrod, "Classic Take on the Industry of One," Crafts January/February (2014): 92.

xvii Defoe, Robinson Crusoe, p. 57.

xviii Defoe, Robinson Crusoe, p. 39.

xix Defoe, Robinson Crusoe, pp. $41-42$.

${ }^{x x}$ Karl Marx, Capital (1) (1867) https://www.marxists.org/archive/marx/works/1867-c1/ch01.htm (last accessed 23 June 2016)

xxi Marx, Capital.

xxii Watt, "Robinson Crusoe, Individualism and the Novel," in Ellis (ed.), Twentieth Century

Interpretations of Robinson Crusoe, pp. 45, 47.

xxiii Watt, "Robinson Crusoe, Individualism and the Novel," in Ellis (ed.), Twentieth Century

Interpretations of Robinson Crusoe, p. 46.

xxiv Stephner Hymer, "Robinson Crusoe and the Secret of Primitive Accumulation," Monthly Review (1971). Reprinted in Monthly Review, 63 (4) (2011) http://monthlyreview.org/2011/09/01/robinsoncrusoe-and-the-secret-of-primitive-accumulation/ (last accessed 17 June 2016).

xxv Jean Baudrillard, "For a Critique of the Political Economy of the Sign," (1981) reprinted in Jean

Baudrillard, Selected Writings, ed. Mark Poster (Cambridge: Polity Press, 1988), pp. 74, 75

xxvi Watt, "Robinson Crusoe, Individualism and the Novel," in Ellis (ed.), Twentieth Century

Interpretations of Robinson Crusoe, p. 50

xxvii Lydia H. Liu, “Robinson Crusoe's Earthenware Pot," Critical Inquiry, 25(4) (1999): 749.

xxviii Harrod, "Classic Take on the Industry of One", 92.

xxix Defoe, Robinson Crusoe, p. 55.

${ }^{\mathrm{xxx}}$ Knott, Amateur Craft, p. xi.

xxxi Knott, Amateur Craft, p. xii.

xxxii Defoe, Robinson Crusoe, pp. $99-102$.

xxxiii Knott, Amateur Craft, xvi.

xxxiv Defoe, Robinson Crusoe, pp. 60, 95.

xxxv Defoe, Robinson Crusoe, p. 96.

xxxvi Defoe, Robinson Crusoe, p. 86

xxxvii Defoe, Robinson Crusoe, p. 84, 86

xxxviii Lehmann, Sophie-Ann, "Showing Making: On Visual Documentation and Making Practice,"

Journal of Modern Craft 5(1) (2012): 9 - 24.

xxix Defoe, Robinson Crusoe, p. 84, 86

${ }^{x l}$ Ingold, Making, pp. $22-23$.

xli William Morris, "Work in a Factory as it Might Be III", Justice, 28th June 1884, p. 2.

https://www.marxists.org/archive/morris/works/1884/justice/13fact3.htm (last accessed 21 June 2016); John Ruskin, "The Nature of Gothic," in Ruskin, Selections and Writings, edited by Frederick William Roe (London: Dover Publications, 2013), p. 327.

xlii Defoe, Robinson Crusoe, pp. 114, 115.

xliii Sennett, The Craftsman.

xliv Rod Edmond and Vanessa Smith, "Editor's Introduction," in Edmond and Smith (eds), Islands in History and Representation (London; New York: Routledge, 2003), pp. 2, 4.

xlv Watt, "Robinson Crusoe, Individualism and the Novel," in Ellis, Twentieth Century Interpretations of Robinson Crusoe, p. 50.

xlvi Claude Lévi-Strauss, The Savage Mind, trans. by George Weidenfeld and Nicholson Ltd (London: Weidenfeld and Nicolson, 1972), pp. 289, $16-17$.

xlvii Trevor Marchand, 'Introduction: Making knowledge: explorations of the indissoluble relation between mind, body, and environment' 14 in Marchand, Making Knowledge)

xlviii Defoe, Robinson Crusoe, pp. 59, 96 - 97

xlix Steven J. Jackson, "Rethinking Repair," in Tarleton Gillespie, Pablo J. Boczkowski, and Kirsten A. Foot (eds.), Media Technologies: Essays on Communication, Materiality, and Society (MIT Press 
Scholarship Online, 2014) DOI: 10.7551/mitpress/9780262525374.001.0001 (last accessed 4 June 2016), pp. 221.

' Navi Radjou, Jugaad Innovation: Think Frugal, be Flexible, Generate Breakthrough Growth (San Francisco, California: Jossey-Bass, 2012); “About the Fab City Project” http://fab.city/about/ (last accessed 20 November 2016)

"i Lydia Kallipoliti, Closed Worlds (New York: Storefront, 2016) exhibition leaflet

lii Crary, 24/7, p. 101.

liii For more on Italian design's engagement with craft see Catharine Rossi, Designing Craft in Italy, from post-war to postmodernism (Manchester: Manchester University Press, 2015).

liv Arturo Carlo Quintavalle, Enzo Mari, (Parma: University of Parma, 1983), p. 270.

${ }^{\text {Iv }}$ For a full discussion of this project, see Rossi, Crafting Design in Italy, from postwar to postmodernism (Manchester: Manchester University Press, 2015), pp. 142 - 148.

Ivi Giulio Carlo Argan, "Tanti Mobili Fatti in Casa," L'Espresso, 5 May 1974 in Quintavalle, Enzo Mari, p. 122.

Ivii Charles Jencks and Nathan Silver, Adhocism: The Case for Improvisation (Cambridge, MA; London: The MIT Press, 2013), inside front cover.

Iviii Charles Jencks and Nathan Silver, Adhocism: The Case for Improvisation (Cambridge, MA; London: The MIT Press, 2013); Victor Buchli, "On Bricolage," in Glenn Adamson and Jane Pavitt (eds),

Postmodernism: Style and Subversion 1970 - 1990, (London: V\&A Publications, 2011), pp. 112 - 116; Irénée Scalbert, "The Architect as Bricoleur," Candide: Journal for Architectural Knowledge 4 (2011): 70.

lix Jencks and Silver, Adhocism, p. viii.

Ix Jencks, Adhocism, p. vii.

${ }^{1 x i}$ Andrea Branzi and Nicoletta Branzi, Domestic Animals: The Neoprimitive Style (Cambridge, MA: MIT Press, 1987), n.p.

'xii Branzi, 'We are the Primitives', (1985/Modo) in Victor Margolin (ed.), Design Discourse: History, Theory, Criticism, (Chicago: University of Chicago Press, 1989) p. 37

Ixiii Gareth Williams, The Furniture Machine: Furniture Since 1990 (London: V\&A Publications, 2006), p. 20.

Ixiv Antonelli, "Nothing Cooler than Dry," in Droog Design: Spirit of the Nineties, ed. by Gijs Bakker and Renny Ramakers (Rotterdam: 010 Publishers, 1998), p. 12.

Ixv Ida Van Zijl, Droog Design 1991 - 1996 (Utrecht: Centraal Museum, 1997), pp. 107, 167.

Ixvi For an earlier perspective by the author on these examples, see Rossi, "Bricolage, Hybridity,

Circularity: Crafting Production Strategies in Critical and Conceptual Design," Design and Culture 5 (1) (2013): $69-88$.

lxvii Douglas Adams, Mostly Harmless, (London: Pan Books, 2009), p. 92.

Ixviii For a full account of the project, see Thomas Thwaites, The Toaster Project: Or, a Heroic Attempt to Build a Simple Electric Appliance from Scratch (New York: Princeton, Architectural Press, 2011).

lxix Stuart Walker, The Handbook of Design for Sustainability (London; New York: Bloomsbury, 2013), p. 397.

Ixx Anon, "Chapter 1: Improvement: The Last Man,"

http://www.stanleypickergallery.org/programme/the-last-man-chapter-1-improvement/ (last accessed 23 June 2016) 